\title{
Oral Findings in Patients with Mucolipidosis Type III
}

\author{
Weber Céo CAVALCANTE ${ }^{1}$ \\ Luciano Cincurá Silva SANTOS ${ }^{1}$ \\ Josiane Nascimento dos SANTOS ${ }^{1}$ \\ Sara Juliana de Abreu de VASCONCELLOS ${ }^{1}$ \\ Roberto Almeida de AZEVEDO ${ }^{1}$ \\ Jean Nunes dos SANTOS ${ }^{2}$ \\ ${ }^{1}$ Department of Oral and Maxillofacial Surgery, Santo Antônio/Irmã Dulce Hospital, Salvador, BA, Brazil \\ ${ }^{2}$ Department of Propedeutics and Integrated Clinics, Dental School, \\ UFBA - Federal University of Bahia, Salvador, BA, Brazil
}

\begin{abstract}
Mucolipidosis type III is a rare, autosomal recessive disorder, which is part of a group of storage diseases as a result of inborn error of lysosomal enzyme metabolism. It is characterized by the gradual onset of signs and symptoms affecting the physical and mental development as well as visual changes, heart, skeletal and joint. Although oral findings associated with mucolipidosis type II have been extensively reported, there is a shortage of information on mucolipidosis type III. This paper presents radiological and histological findings of multiple radiolucent lesions associated with impacted teeth in the jaw of a 16 year-old youngster with mucolipidosis type III.
\end{abstract}

Key Words: mucolipidosis, pseudo-Hurler's syndrome, lysosomal metabolic diseases, storage disease.

\section{INTRODUCTION}

The extracellular matrix and the cell surface are composed by various molecular components, in which are found the proteoglycans. These substances are linked covalently to the glycosaminoglycans, which are catabolized, gradually, by the lysosomal enzymes. Because of the genetic alterations, the post-translational modification of these lysosomal enzymes promotes the appearance of these clinical conditions characterized as mucolipidosis (1).

The lysosomal enzymes are addressed to the lysosomes by post-translational addition of the mannose-6-phosphate, reaction, which is characterized by the phosphotransferase enzyme. Phosphotransferase deficiency results in the incapacity to catabolize all of glycosaminoglycans. Thus, the enzymes responsible for catabolizing the glycosaminoglycans fail to be transported to the interior of the lysosomes and accumulate at high concentrations in the plasma, serving as a diagnostic evidence for mucolipidosis (2).

Mucolipidosis can be classified into 4 categories: type I, characterized by the deficiency of the lysosomal enzyme sialidase; types II (inclusion-cell disease) and III (pseudo Hurler polydystrophy), which are caused by deficiency of the enzyme N-acetylglucosaminy-1phosphotransferase (NAGFT), and type IV, caused by he deficiency of the mucolipin enzyme (3).

Deficiency of the enzyme $\mathrm{N}$-acetylglucosaminyl1-phosphotransferase is the fundamental cause of the mucolipidosis types II and III, and the differential diagnosis is based on the age of occurrence, clinical symptoms and severity $(4,5)$. Also known as pseudoHurler polydystrophy, mucolipidosis type III (ML III) appears to be milder than the mucolipidosis type II (ML II), in which patients exhibit coarse facial features, early restricted joint movements and a more severe psychomotor delay (6). In ML III, the symptoms appear later on, with reports of survival rate until adulthood and no reports of oral findings (3).

Correspondence: Dr. Weber Céo Cavalcante, Rua Ismar Prates, lote 62 casa 38, Condomínio Morada do Joanes, Buraquinho, $42700-000$ Lauro de Freitas, BA, Brasil. Tel/Fax: +55-71-8801-4444. e-mail: weberceo@ig.com.br 
This paper reports a case of ML III with oral involvement in a young patient.

\section{CASE REPORT}

A 16-year-old Caucasian female patient was referred to the Department of Oral Maxillofacial Surgery and Traumatology of the Federal University of Bahia, Brazil, by a general dentist due to the presence of impacted teeth in the maxilla and mandible.

The adolescent was the only daughter of a nonconsanguineous couple, father and mother with 48 years of age. The child was born at term through a cesarean section, with weight of $3.750 \mathrm{~kg}$ and height of $44 \mathrm{~cm}$. Around 5 years of age, skeletal alterations were detected, manifested by joint stiffness, low weight and height development and difficulty to run and go up stairs. The patient had normal neurological development for her age, attending the ninth grade of high school.

In the extraoral physical exam, it was noted that the patient showed good general condition, long biotype, short necked, protruded thorax, anicteric, eupneic, decreased flexibility at the hands, elbows, shoulders, knees and cervical region, short neck, slightly coarse face, and good lip seal (Figs. 1 and 2A).

Ophthalmological, neurological, cardiac and urological exams were done at the Clinics Hospital of the Federal Universtity of Bahia (HUPES) and did not reveal any alterations in the patterns of normalcy. The orthopedic examination, also conducted at HUPES, found that the patient had skeletal dysmorphism, decreased joint movement, bent knees and shortening of the 5 th toe.

The patient underwent laboratory tests accompanied by the genetic service of HUPES, such as urine and plasma. The presence of arylsulfatase A, lysosomal enzyme serum, which summed to the nonaggressive phenotypic aspect of the disease favored to the final diagnosis of the ML III.

Intraoral examination revealed malocclusion, dental rotation, absence of the second and third molars, as well as the first inferior molars. No anterior open bite was observed (Fig. 2B-D).

Analysis of the panoramic radiograph showed well delimited radiolucent images, involving impacted teeth in the mandible and maxilla, compatible with cystic
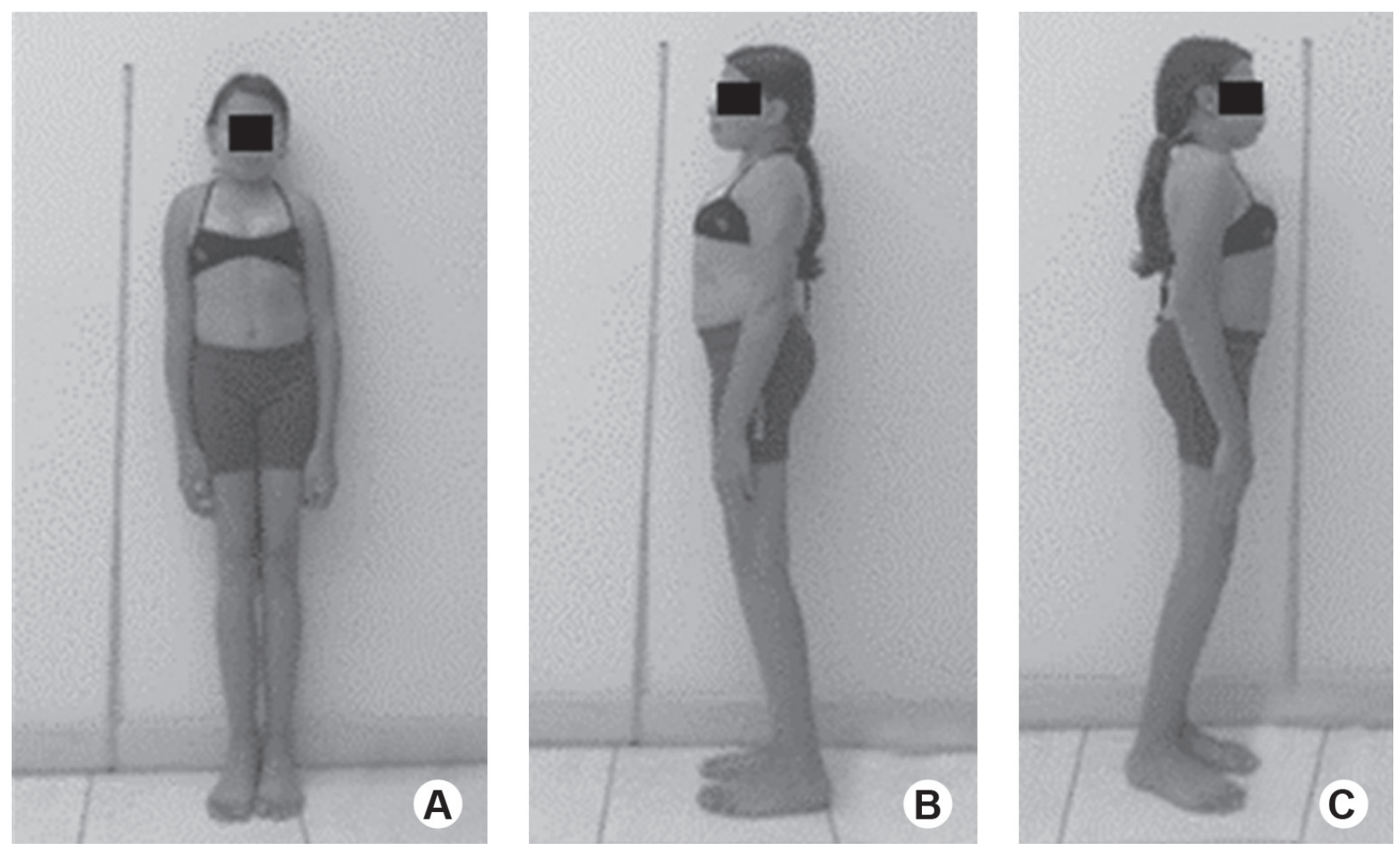

Figure 1. A 16 year-old youngster with ML III, exhibiting long biotype, short stature (1.5 m), protruded thorax and joint stiffness (A-B). 
images (Fig. 3).

The patient was referred to the surgical Center of the Santo Antônio Hospital, Salvador, BA, Brazil, and submitted to surgical procedure under general anesthesia for the removal of multiple retained dental units.

During the surgical procedure, it was found thick fibrous material adhered to teeth $17,18,27,28,36,37$, $38,46,47$ and 48 (Fig. 4A). All the material collected in the surgery was sent for histopathological analysis at the Department of Surgical Pathology of the Dental School, Federal University of Bahia. The patient recovered well postoperatively, without complications.

The histopathological analysis revealed a fibrous tissue rich in collagen fibers, with the presence of odontogenic epithelial remains, spots of mineralization
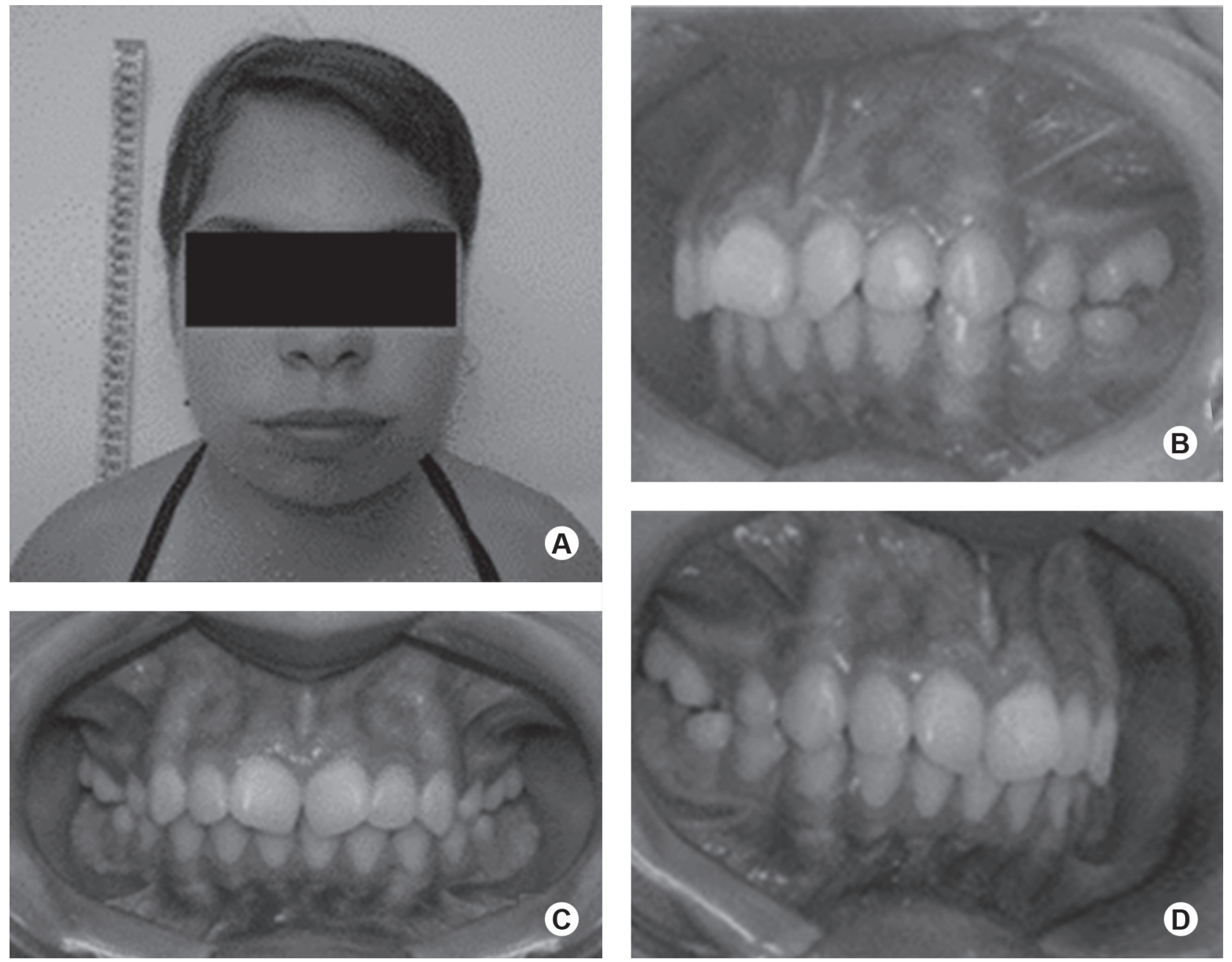

Figure 2. Extraoral examination demonstrating short neck, slightly coarse face, and good lip seal (A). Intraoral examination showing malocclusion, dental rotation, absence of teeth 18, 17, 27, 28, 36, 37, 38, 46, 47 and 48 (B, C and D). and discreet lymphocyte infiltrate compatible with normal dental follicle, though thick (Fig. 4B-D).

\section{DISCUSSION}

The literature demonstrates oral repercussions of ML II, however, it does not mention such findings in type III. Among the oral manifestations found in ML II are gingival and alveolar thickness evolving to open bite. Other findings are delayed tooth eruption, dental impaction, dental hypocalcification, lack of lip seal and accumulation of mucolipidic material at the dental follicle (7-9). As to the case presented, delay in the dental eruption and the presence of impacted teeth were also present, however, open bite and lack of lip 
seal were not observed.

Clinical manifestations of ML III include partial dystrophy like Hurler's syndrome or mucopolysaccharide type I, characterized by short stature. Another clinical manifestation is mental deficiency, in a lesser degree when compared with ML II. Valvular cardiac diseases and corneal opacities are also reported. Among the ML III manifestations, the skeletal alterations are the

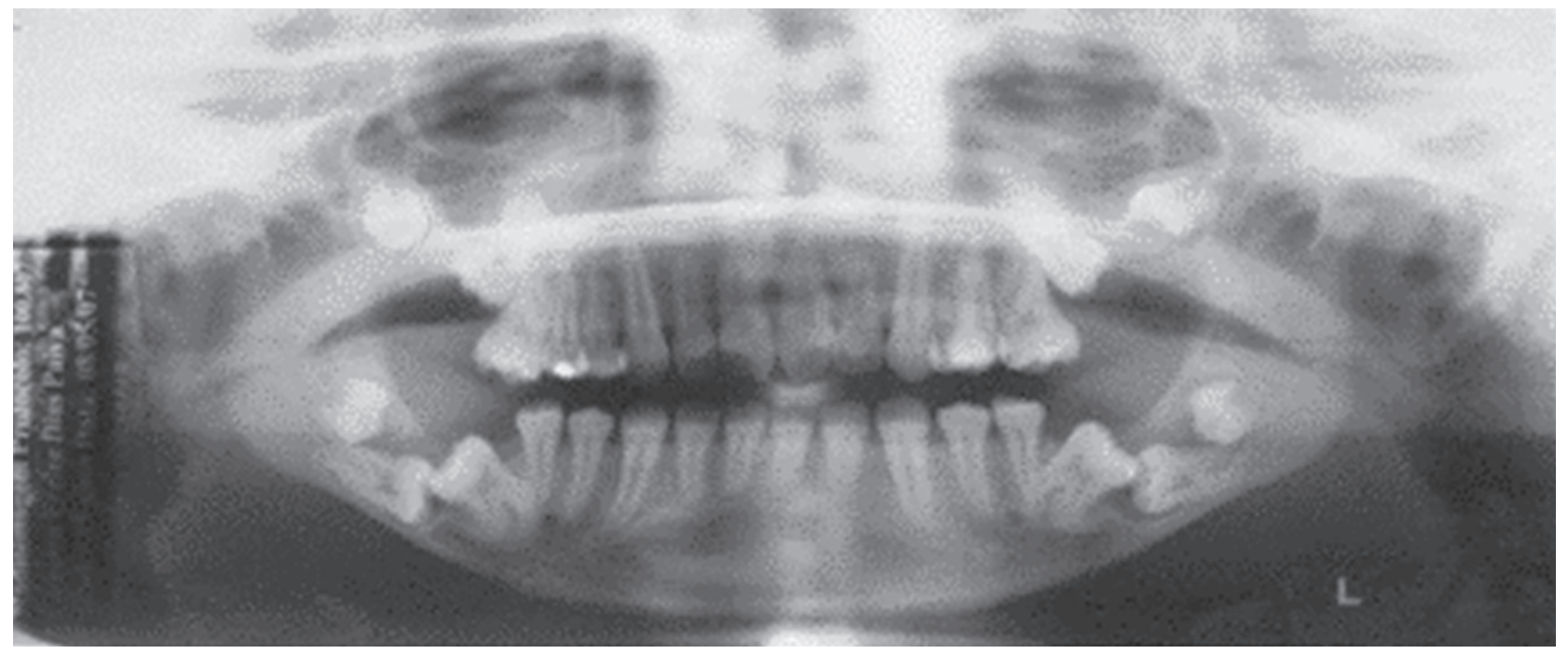

Figure 3. Panoramic radiograph showing radiolucent images associated with impacted teeth.
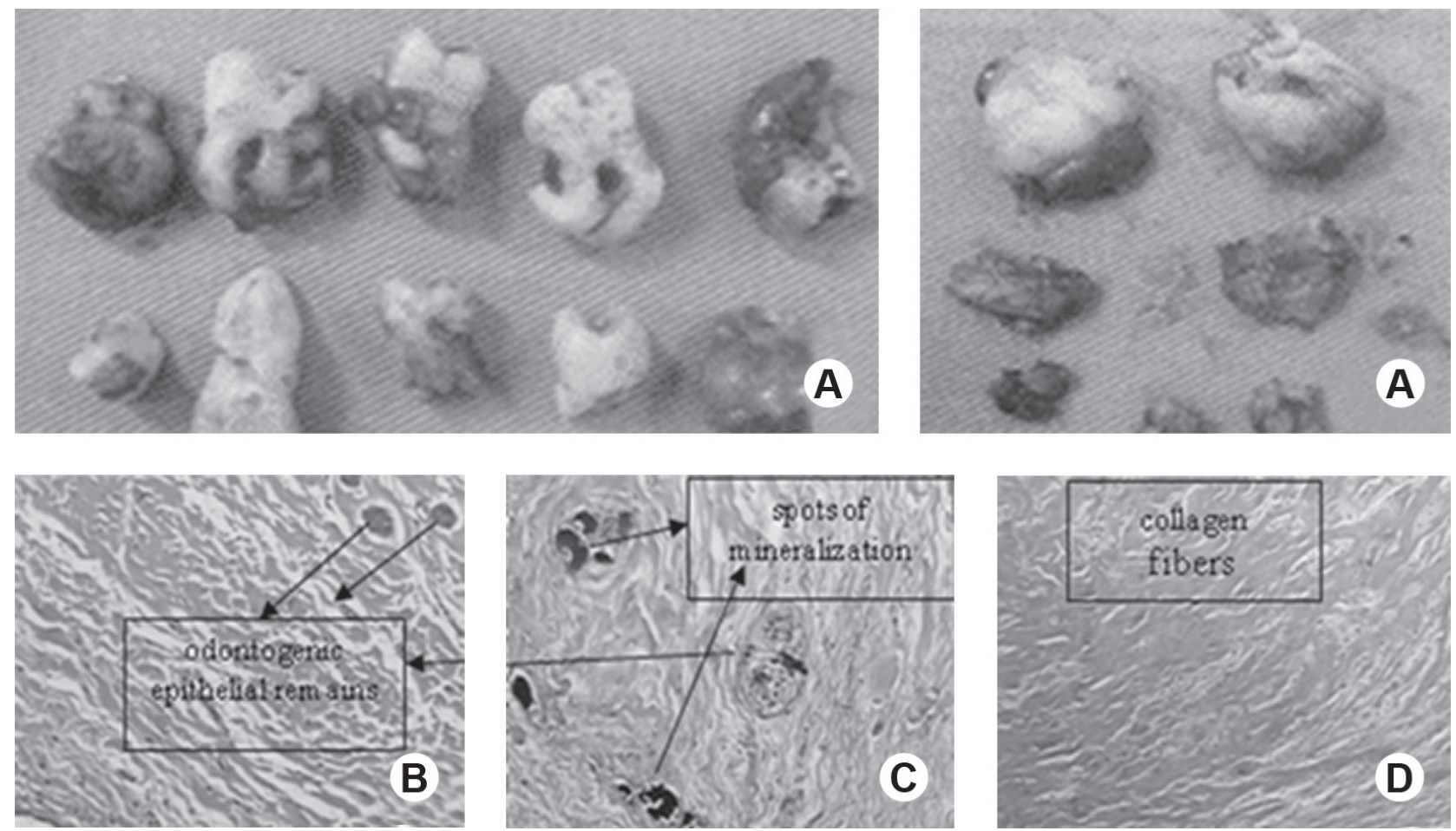

Figure 4. Impacted teeth surrounded with fibrous consistent tissue (A). Histological images with hematoxylin and eosin staining at magnifications $\times 100, \times 100$ and $\times 40$, respectively $(\mathrm{B}, \mathrm{C}$ and $\mathrm{D})$, demonstrating the predominance of collagen fibers, some odontogenic epithelial remains with spots of mineralization. 
most discussed in the literature, which suggest the characterization of these diseases by the high turnover rate of bone metabolism in a disordered manner (10). Skeletal and orthopedic complications of ML III include hand and shoulders stiffness, claw-hand deformities, scoliosis, short iliac wings, erosion of the femoral heads, underdevelopment of the posterior elements of the dorsal spine and multiple dysostosis of the skull, vertebral bodies, long bones, clavicles and phalanges, which were observed in the present case (11). As to the intraoral manifestations, the only finding recorded in the literature, until the moment, refers to the abnormal dental spacing (10), which was observed in this case.

There is only one reported case in the literature relating ML III to a severe destruction of the temporomandibular joint, leading to dysphagia and dysphonia, and requiring gastronomy tube placement, but without mentioning intraoral findings (12). No temporomandibular joint alterations were observed in our patient.

It is believed that the clinical skeletal manifestations of this disease are due to the fact that mannose-6phosphate (M-6-P) also acts in the osteoclastic activity. The osteoclastic lysosomal enzymes, destined for excretion are produced with the aid of this molecule. As a compensatory effect of the lack of these enzymes which are dependent of the mannose-6-phosphate this acid phosphatase seems to be produced in abundance, causing the clinical signs and symptoms observed in mucolipidosis (10).

The diagnosis of ML III is based on clinical and laboratory findings. Short stature, joint alterations in hips, knees, elbows and spine, are referred clinical reports, also observed in the patient studied. The hematologic laboratory findings of patients with ML III involve the presence of some lysosomal enzymes including arylsulfatase, an enzyme found in the case reported herein (3).

The treatment of ML III is essentially symptomatic and palliative. The use of intravenous pamidronate has been combined with drug treatment with the aim of reducing bone repercussions of such disease. Pamidronate is a highly potent bisphophonate widely used in the treatment of patients with bone metastasis from prostate and breast cancer. Bisphosphonates are known for their high affinity for the hydroxyapatite, and are synthetic analogs of the pyrophosphate, which is a physiological regulator of calcification and bone resorption, naturally present in urine and serum. The action of bisphosphonates is due to the structural similarity with this compound group. Bisphosphonates act indirectly in bone resorption by attaching to the hydroxyapatite crystals, and directly by either inactivating or decreasing the activity of osteoclasts, depending on the type and/or concentration of the drug used $(10,13)$. However, the association of osteonecrosis of the maxilla and mandible with the use of this type of bisphosphonate has been reported (14-17). The patient of the present case did not use this drug.

Based on the oral findings of the present case, it can be stated that the ML III, in the same way ML II, also has specific oral manifestations, which shall be diagnosed and treated as early as possible in order to improve the health conditions of their carriers.

\section{RESUMO}

A mucolipidose tipo III é uma doença rara, autossômica recessiva, que faz parte de um grupo de doenças de depósito, decorrentes do erro inato do metabolismo das enzimas lisossômicas. Caracterizase pelo aparecimento progressivo de sinais e sintomas com repercussão no desenvolvimento físico e mental, bem como alterações visuais, cardíacas, esqueléticas e articulares. Apesar de achados bucais estarem bem relatados em associação à mucolipidose tipo II, esse artigo descreve achados radiográficos e histológicos de múltiplas lesões radiolúcidas, associadas a dentes inclusos nos maxilares, em uma jovem de 16 anos de idade com mucolipidose tipo III.

\section{REFERENCES}

1. Meikle PJ, Grasby DJ, Dean CJ, Lang DL, Bockmann M, Whittle AM, et al.. Newborn screening for lysosomal storage disorders. Mol Genet Metab 2006;88:307-314.

2. Hasilik A, Wahbed A, Cantz M, Figura KV. Impaired phosphorylation of lysosomal enzymes in fibroblasts of patients with Mucolipidosis III. Eur J Biochem 1982;122:119-123.

3. Castroviejo AS, Miranda JRV, Miranda MIV, Magalhães AF. Mucolipidosis type III - pseudo-Hurler: a case description. Rev Paul Pediatria 2005:23:49-53.

4. Bargal R, Zeigler M, Abu-Libdeh B, Zuri V, Mandel H, Ben Neriah Z, et al.. When Mucolipidosis III meets Mucolipidosis II: GNPTA gene mutations in 24 patients. Mol Genet Metab 2006;88:359-363.

5. Coutinho MF, Prata MJ, Alves S. Mannose-6-phosphate pathway: a review on its role in lysosomal function and dysfunction. Mol Genet Metab 2012;105:542-550.

6 Chen M, Ke YY, Chang SP, Lee DJ, Chen CH, Ma GC. Prenatal transient alveolomaxillary defect in a case of Mucolipidosis II (I-cell disease). Ultrasound Obstet Gynecol 2010;36:255-258.

7. Lee $\mathrm{W}, \mathrm{O}^{\prime}$ Donnell $\mathrm{D}$. Severe gingival hyperplasia in a child with I-cell disease. Int J Paediatr Dent 2003;13:41-45.

8. Melo MD, Obeid G. Radiolucent lesions of the maxillofacial complex in a patient with mucolipidosis type II (MLSII): case report. Oral Surg Oral Med Oral Pathol Oral Radiol Endod 2007;104:30-33. 
9. Nishimura F, Naruishi H, Naruishi K, Yamada T, Sasaki J, Peters $\mathrm{C}$, et al.. Cathepsin-L, a key molecule in the pathogenesis of drug-induced and I-cell disease-mediated gingival overgrowth. Am J Pathol 2002;161:2047-2052.

10. Robinson C, Baker N, Noble J, King A, David G, Sillence D, et al.. The osteodystrophy of Mucolipidosis type III and the effects of intravenous pamidronate treatment. J Inherit Metab Dis 2002;25:681-693.

11. Afshar A. Bilateral carpal tunnel syndrome and multiple trigger fingers in a child with mucolipidosis Type III disease. Indian J Plast Surg 2011;44:517-520.

12. Zolkipli Z, Noimark L, Owens MACC, Vellodi A. Temporomandibular joint destruction in Mucolipidosis type III necessitating gastrostomy insertion. Eur J Pediatr 2005; 164:772774.

13. Castro LF. Bisphosphonates as osteotropic carriers for designing site-directed drugs. Quim Nova 2004;27:456-560.

14. Marx RE. Bisphosphonate- induced exposed bone (osteonecrosis/ osteopetrosis) of the jaws: risk factors, recognition, prevention, and treatment. J Oral Maxillofac Surg 2005;63:1567-1575.

15. Berkau I, Weißbarth-Riede E, Lüttgen S, Lukacs Z, Gal A, Braulke T, et al.. Analysis of phosphotransferase expression and lysosomal sorting in a family with a mild clinical phenotype of mucolipidosis. Acta Paediatr 2008;97:120.

16. Schwartz IVD, Medeiros MS, Federhen A, Burin M, Coelho J, Giugliani R. Mucolipidosis II and III in Brazil: a review of the cases diagnosed by a reference centre. Acta Paediatr 2008;97(s457):106-113.

17. Tiede S, Storch S, Lübke T, Henrissat B, Bargal R, Poorthuis B, et al.. Correction of lysosomal missorting in Mucolipidosis II fibroblasts by retroviral expression of N-acetylglucosamine-1phosphotransferase. Acta Paediatr 2007;96:109-110.

Received November 29, 2011

Accepted September 13, 2012 